Семененко В. М., канд. техн. наук, ст. наук. співроб. ${ }^{1}$

1 - Центр воєнно-стратегічних досліджень Національного університету оборони України імені Івана Черняховського, Київ;

1 - Навчально-науковий центр стратегічних комунікацій у сфері забезпечення національної безпеки та оборони Національного університету оборони України імені Івана Черняховського, Київ

\title{
Культура стратегічних комунікацій як основа таргетингу
}

Резюме. У статті проведено аналіз ролі культури стратегічних комунікацій як основи таргетингу, надано рекомендації щодо формування культури стратегічних комунікацій у процесі реалізації і розвитку комунікаційних можливостей держави.

Ключові слова: стратегічні комунікації; культура; таргетинг.

Постановка проблеми. Декілька років поспіль чинні національні програми під егідою Комісії Україна - НАТО $[1,2]$, затверджені відповідними указами Президента України, задекларували розвиток в Україні культури стратегічних комунікацій на інституційному рівні, налагодження більш тісного співробітництва 3 неурядовими організаціями й сприяння розвитку їх спроможності здійснювати стратегічні комунікації в інтересах України.

Згідно 3 визначеннями Доктрини зі стратегічних комунікацій [5], стратегічні комунікаиії - скоординоване i належне використання комунікативних можливостей держави - публічної дипломатії, зв'язків 3 громадськістю, військових зв'язків, інформаційних і психологічних операцій, інших суб'єктів інформаційної діяльності для виконання заходів, спрямованих на просування цілей держави.

Стратегічні комунікації у Збройних Силах (3С) України - об'єднання комунікативних спроможностей та військової діяльності 3 метою формування інформаційного середовища для розуміння, підтримання українським суспільством та міжнародною спільнотою діяльності ЗС України, створення сприятливих умов для виконання ними завдань за призначенням [5].

Однак на сьогодні наукові підходи до стратегічних комунікацій як культури, а також до обгрунтування ролі культури стратегічних комунікацій у прийнятих країнами НАТО процесах таргетингу залишаються недостатньо розкритими та науковообгрунтованими.

Аналіз основних досліджень i публікацій. У [3] обгрунтована структура системи стратегічних комунікацій Міністерства оборони (МО) та 3С України як складника загальнодержавної системи комунікацій, доведена направленість процесів, які відбуваються під час комунікацій, на підвищення результативності процесів управління військами.

Автори [4] обгрунтовують доцільність формування Ситуаційного центру стратегічних комунікацій МО України та ЗС України, визначають його роль і місце у загальнодержавній системі, структуру, основні завдання та алгоритм роботи.

У [5] окреслюється роль і місце стратегічних комунікацій у структурі 3С України, а [6] відображає систему поглядів, керівні принципи, умови і шляхи досягнення мети військового лідерства та практичного впровадження у підготовку i застосування військ (сил), як концепту внутрішніх комунікацій. У [7] проведено аналіз результатів роботи високомобільної групи внутрішніх комунікацій у штабах $\mathrm{i}$ підрозділах Об'єднаних сил, надано рекомендації щодо застосування технологій внутрішніх комунікацій у процесах управління збройними силами, як складової стратегічних комунікацій. Джерела [8-15] розкривають підходи НАТО щодо реалізації стратегічних комунікацій та їх складових.

Однак питання сутності культури стратегічних комунікацій в означених роботах не розглядаються.

Метою статті $\epsilon$ аналіз культури стратегічних комунікацій, як основи таргетингу та розроблення пропозицій щодо іiі формування.

Виклад основного матеріалу. У сучасному інформаційному середовищі послідовне i своєчасне застосування стратегічних комунікацій має вирішальне значення для загального успіху, особливо у протистоянні загрозам, які створюються 
агресором у гібридній війні. Для досягнення успіху, сили безпеки i оборони мають максимально ефективно застосовувати всі елементи стратегічних комунікацій, бути гнучкими і активними, намагатись завоювати панування в межах інформаційного середовища, тобто досягнути такого стану, коли взаємодія між суб'єктами стратегічних комунікацій підсилює зусилля один одного, робить оптимальним використання дефіцитних ресурсів.

Характер сучасних загроз в інформаційній сфері розмиває традиційні рамки миру i війни, тому стратегічні комунікації мають бути організовані та діяти ефективно як в мирний час, так і у складних умовах криз і воєнних конфліктів. Основним фактором формування складних умов $\epsilon$ нестача або неефективне використання наявних людських i матеріальних ресурсів. Подолання цих умов потребує точного таргетингу (націлювання) i постійного удосконалення як політики, так i безпосередньо функцій стратегічних комунікацій, зокрема, організаційної (планувальної), виконавчої (координаційної) i контрольної (коригувальної) складових комунікаційної діяльності.

У НАТО справедливо вважають [15], що використання летальних i нелетальних можливостей впливає на інформаційне середовище або позитивно, узгоджуючи дії зі словами, або негативно, суперечачи повідомленням НАТО для аудиторії або завдаючи шкоди місії в зоні операцій і поза нею. Усі цільові заходи мають узгоджуватися iз замислом стратегічних комунікацій НАТО та наративом місії (наратив - соціальна конструкція, когерентно взаємопов'язана між собою послідовність історичних і поточних подій [10], яка пояснює мотив місії).

За визначенням НАТО [15] таргет (ціль) - це структура, об'єкт, особа чи група осіб, проти яких може бути застосовані летальні чи нелетальні можливості для створення конкретних психологічних чи фізичних ефектів. Поняття "особа" включає мислення, процес мислення, іiі ставлення до чогось і поведінку.

Процес таргетингу - це спільні, системні та цілеспрямовані летальні та нелетальні дії стратегічного, оперативного i тактичного рівнів для створення конкретних ефектів, досягнення військових цілей i бажаного кінцевого стану [15]. Згідно 3 принципами, викладеними в Конституції України, бажаним кінцевим станом для
України можна вважати такий стан національної безпеки i оборони, який гарантуватиме захист суверенітету i територіальної цілісності України, забезпечення іiі економічної та інформаційної безпеки.

Для того, щоб інформаційні та комунікаційні аспекти летальних та нелетальних дій були зрозумілими та прийнятними для суспільства i всіх рівнів військового управління, процеси стратегічних комунікацій MO i 3С України мають бути цілеспрямованими, узгодженими, продуктивними, простими i своєчасними, опиратись на досвід, бути ціннісноорієнтованими, а також гармонійно інтегрованими в життєдіяльність сил безпеки та оборони.

Усе це потребує створення у внутрішньому та зовнішньому середовищі матеріальних i духовних цінностей через реалізацію комунікативних можливостей держави, постійний розвиток і удосконалення цих можливостей завдяки максимальному використанню набутого досвіду i ефективному використанню ресурсів для гармонізації заходів, спрямованих на просування цілей держави, тобто потребує таргетингу i підходів до стратегічних комунікацій, як культури, яка забезпечить досягнення військових цілей i бажаного кінцевого стану.

3 огляду на загальноприйняте визначення поняття “культура" (від лат. culture - “обробіток”, “обробляти”) i “стратегічні комунікації” [5] пропонується таке визначення культури стратегічних комунікащій - сукупність матеріальних і духовних цінностей, створених у процесі реалізації комунікативних можливостей держави, історично набутий досвід і рівень їх розвитку для удосконалення та гармонізації заходів, спрямованих на просування цілей держави в майбутньому.

Хоча культура стратегічних комунікацій не $\epsilon$ кінцевим продуктом, вона $\epsilon$ важливим фактором, який гарантує залучення великої кількість людей-однодумців, значну результативність, сприяє розвитку структури, зокрема, ЗС України i суспільства, i міжнародних відносин України.

У НАTO стратегічні комунікації розглядаються як спосіб мислення, який передбачає ширше розуміння комунікацій, як таких, що виходять за межі традиційних засобів масової інформації та некінетичних 
підходів до досягнення бажаних ефектів в інформаційному середовищі.

Менталітет (англ. mindset - система мислення, ментальність, свідомість) сукупність соціально-психологічних настанов, загальна духовна налаштованість, установка до навколишнього світу.

Менталітет виконавців і планувальників операцій має забезпечувати розуміння того, як ті чи інші дії або слова НАТО будуть сприйняті в інформаційному середовищі в будь-який час. Це мислення має пронизувати всі рівні від стратегічного (оперативного) до тактичного. Персонал має включати фахівців (експертів) за всіма напрямами комунікативних

спроможностей

та інформаційних функцій персоналу, що дасть змогу забезпечити розуміння наративів Альянсу завдяки культурній обізнаності, єдності зусиль, послідовності, достовірності та застосовності продуктів стратегічних комунікацій [10].

3 огляду на це можна дійти висновку, що "mindset" $є$ основою культури стратегічних комунікацій НАТО.

У НАТО [10] також задекларовані та діють принципи стратегічних комунікацій, які $\epsilon$ складовими культури стратегічних комунікацій (рис. 1).

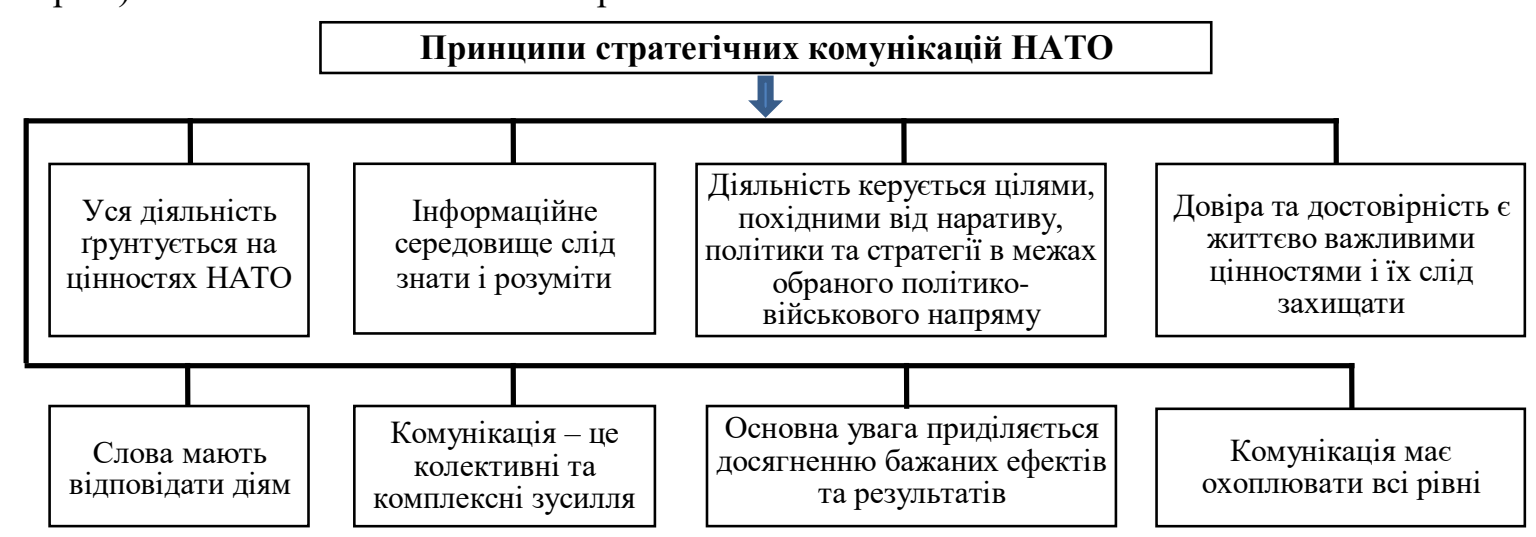

Рис. 1. Принципи стратегічних комунікацій НАТО

В Україні реалізація згаданих принципів ускладнюється тим, що управління кризовими ситуаціями та кризові комунікації часто знаходяться під впливом політичної боротьби і рідко грунтуються виключно на реальності. Ситуація, яку можна охарактеризувати як кризову, і яка $\epsilon$ поширеною у ЗМІ, зазвичай пов'язана з намаганням якоїсь політичної сили використати гучну подію як інформаційний привід для дискредитації МО та ЗС України для досягнення власних політичних інтересів.
У цій ситуації військові структури не мають великої кількості можливостей цілісних комунікацій із зовнішніми аудиторіями, оскільки не мають доступу до засобів масової інформації, які здебільшого належать приватним особам і ведуть свою редакційну політику.

Зважаючи на це доцільно ширше використовувати різні доступні види комунікацій. За поглядами НАТО види комунікацій наведено на рис. 2.

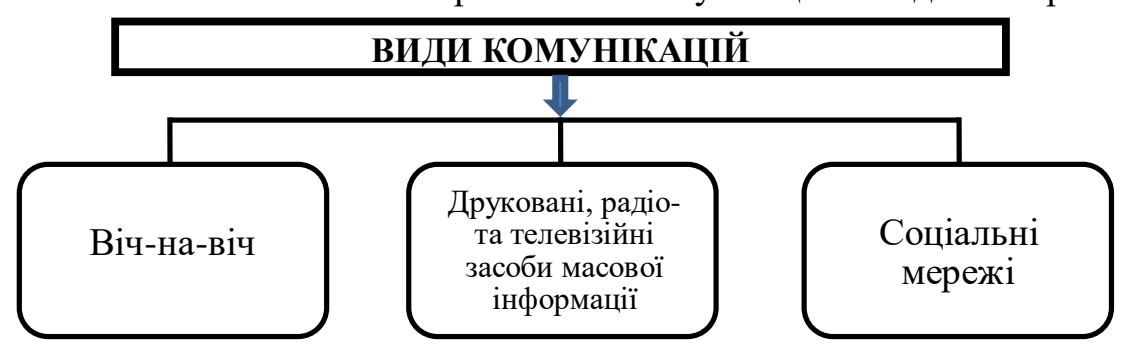

Рис. 2. Види комунікацій

Комунікачія віч-на-віч. Спілкування вічна-віч вважається найвпливовішим засобом комунікації. Командири i старші посадові особи відіграють життєво важливу роль у справі надання (поширення повідомлень) (меседжів) завдяки їх взаємодії з головними лідерами (керівниками) важливих груп та організацій. Спілкування віч-на-віч не $\epsilon$ спонтанним процесом. Кожне таке залучення керівників має бути добре підготовленим, організованим, проведеним та оціненим. Для підготовки командувача потрібна допомога експертів 3 комунікації (фахівців 3 інформаційних операцій, психологічних портретів тих, 3 ким він зустрічатиметься, аналітиків із соціокультурних аспектів). 
Традичійні друковані, радіо- та телевізійні засоби масової інформамії. Наполегливо рекомендується, щоб увесь особовий склад отримав підготовку зі спілкування 3 журналістами, дотримуючись інформаційної стратегії та наративів, розроблених правил забезпечення безпеки операцій.

Традиційні тактики в спілкуванні i відносинах із 3MI, є надзвичайно важливими, хоча вони часто функціонують на основі традиційної моделі одностороннього спілкування, реагування на кризові ситуації.

Стандартними інструментами зв'язків із 3МI, які застосовуються в установах, $є$ пресконференція, брифінг у пресі, прес-реліз, відвідування театру, фотосесія, інтерв'ю, публічна заява тощо. Якість інформаційного продукту значно впливає на висвітлення подій у засобах масової інформації, це також один 3 головних обов'язків практикуючого командира або комунікатора. Незалежно від проактивності, фахівці зі стратегічних комунікацій, командири мають усвідомлювати, що кожна комунікація дорогоцінна. Втративши ії один раз, відновити довіру або інтерес буде дуже важко. Отже новини не мають базуватися лише на інформації, яку організація хоче бачити у відкритому доступі, а на потребах цільових аудиторій.

Соиіальні мережі (сочіальні медіа). Останніми роками соціальні мережі стають популярнішими. Середовище соціальних засобів масової інформації постійно засвідчуе зміни в технологіях і комп'ютерних системах. Для багатьох соціальних груп соціальні мережі є невід'ємною частиною їх щоденного споживання інформації. Соціальні мережі надають безліч можливості спілкуватися, взаємодіяти або ділитися контентом різного типу - від тексту до відео, від зображень до геолокаційних даних тощо. Військові недостатньо розуміють соціальні мережі та їх значення у військових операціях, тому їм краще вивчити простір соціальних мереж, їх користувачів, їх інтереси i способи комунікації, і те, як соціальні мережі можуть бути використані як додатковий канал комунікації. Як і всі інші засоби масової інформації, соціальні мережі треба використовувати скоординовано. Перед початком ведення комунікації на каналах соціальних мереж ретельно оцінюють вихідні умови. До того ж військовим необхідно зрозуміти, які соціальні групи використовують соціальні мережі, 3 якою метою, як вони спілкуються в Інтернеті, їх інтереси і перебування соціальних груп. Також треба оцінювати відповідну інфраструктуру, ступінь доступу до Інтернету, чи використовує більшість людей смартфони для доступу в Інтернет тощо. Цю базову оцінку потім використовують для розроблення комунікаційної (інформаційної) стратегії, яку вибирає, й інформує про комунікаційні аспекти соціальних мереж.

Цифровізація (діджиталізація), особливо факт збільшення осіб, які використовують Інтернет i Facebook на щоденній основі, запропонували нові можливості спілкування 3 цільовими аудиторіями. Ці нові технології змінили спосіб спілкування культурних інституцій зі своєю аудиторією $з$ нуля, тобто нові технології здійснили революцію середовища, де споживачі культурних продуктів отримують поінформованість i спосіб комунікації.

Знання реалій та вміння налагоджувати комунікації, вміння ефективно і успішно взаємодіяти 3 лідерами (керівниками) важливих груп та організацій, представниками та використовувати їх можливості, опираючись на загальнолюдські та загальнодержавні цінності, також є важливим елементом культури стратегічних комунікацій.

Успішні стратегічні комунікації потребують не лише взаємодії суспільних суб'єктів, сукупності ціннісних характеристик щодо розуміння, мотивації, поведінки, ставлення, сприйняття, думок, скарг і проблем суб'єктів, які змінюються 3 плином часу, а й чіткого таргетингу (націлювання) на конкретні цілі.

В умовах обмежених ресурсів робота професіонала - фахівця стратегічних комунікацій МО та ЗС України - має бути зорієнтована на вироблення якісного продукту $\mathrm{i}$ досягнення конкретних цілей. Зазначене потребує інноваційних підходів, творчості, постійного моніторингу інформаційного середовища i технологій задля адаптації продукту стратегічних комунікацій до змін і тенденцій розвитку комунікацій в інформаційному середовищі. У командному контексті культура стратегічних комунікацій розуміється як мистецтво внутрішніх комунікацій, спосіб життя організації, тому можна припустити, що культура стратегічних комунікацій становить основу таргетингу.

Таргетинг (націлення) передує створенню комунікативних стратегій, на які впливає політична та фінансова стабільність, 
нормативні документи, кадрове забезпечення, технологічний розвиток, стихійні лиха, демографічні, духовні та матеріальні здобутки населення.

Цифровізація (діджиталізація), особливо факт збільшення осіб, які використовують Інтернет i Facebook на щоденній основi, запропонували нові можливості спілкування 3 цільовими аудиторіями. Ці нові технології змінили спосіб спілкування культурних інституцій зі своєю аудиторією 3 нуля, або краще сказати, що нові технології здійснили революцію середовища, де споживачі культурних продуктів отримують поінформованість і спосіб комунікації.

Після розуміння сутності культури стратегічних комунікації важливим $\epsilon$ вироблення пропозицій щодо формування культури стратегічних комунікацій в МО та ЗС України.

Погляд у майбутнє $\epsilon$ надзвичайно важливим для формування культури стратегічних комунікацій в МО та ЗС України. Основні пропозиції щодо формування культури стратегічних комунікацій в МО та ЗС України можуть бути представлені такими вимогами до компетентностей суб'єктів стратегічних комунікацій: розуміння процесу планування та управління, знання інструментів i методів, специфічних для виконання функцій стратегічних комунікацій, розуміння спеціалізованих засобів комунікації, розуміння бажань і потреб споживачів - цільової аудиторії, моніторинг тенденцій, гнучкість, прийняття нових тенденцій i усвідомлення того, що інструменти, канали та тенденції постійно змінюються технологічним прогресом.

Продукт стратегічних комунікацій, як і будь-який інший інформаційний продукт, стає все більш чутливим до втручань і впливів, що викликає необхідність стратегічного передбачення та систематичного аналізу нових тенденцій розвитку внутрішнього i зовнішнього інформаційного середовища.

Аналіз інформаційного середовища i стану стратегічних комунікацій дає уявлення про інституцію 3 трьох аспектів: внутрішне оточення (місія, бачення та внутрішня структура), сприйняття суспільства (репутація) та зовнішнє оточення (зацікавлені сторони).

Після аналізу внутрішнього i зовнішнього інформаційного середовища, аналізу потреб цільових аудиторій i визначення стратегії, яка має коригувати організаційну (планувальну), виконавчу (координаційну) функції стратегічних комунікацій, необхідно визначити реальні роль i місце стратегічних комунікацій у свідомості (mindset) військових керівників лідерів.

Визначення ролі та місця стратегічних комунікацій у свідомості лідерів $\epsilon$ вкрай важливим для вибору стратегії i тактики реалізації проєкту формування культури стратегічних комунікацій у МО і ЗС України, водночас і найскладнішою частиною процесу удосконалення пов'язаних 3 цим відносин. Адже, будь-яка спроба удосконалення завжди наражається на скепсис, саботаж, прихований або відкритий спротив. Будь-яке поліпшення, зазвичай, йде в розріз з інтересами окремих особистостей. Це можуть бути іміджеві, статусні, фінансові або інші інтереси. Причиною конфлікту інтересів також можуть бути особисте несприйняття нового, слабо розвинуті ціннісні та фахові компетенції тощо.

Стратегія є основою, на якій будується модель формування цієї культури. Ця стратегія має містити бачення, як досягти встановлених цілей і подолати проблеми в тій тактики реалізації програми змін, які поєднують в собі набір форм, методів i часових показників.

Лідерство i воля керівника проєкту, засновані на ідеї позитивних змін, чітке бачення цілей i результатів, коаліція союзників мають стати рушійними силами реалізації цієї стратегії.

Креативна стратегія формування культури стратегічних комунікацій допоможе інституції наростити імідж i репутацію, отримати конкурентні переваги та зміцнити інституцію, досягнути необхідних ефектів, зокрема визнання лідера суспільством. Таргетинг забезпечить оптимальні шляхи досягнення лідером своєї місії.

Висновок. Успішна комунікація потребує сукупності ціннісних характеристик суб'єктів стратегічних комунікацій щодо розуміння, мотивації, поведінки, ставлення, сприйняття думок щодо вирішення проблем налагодження комунікацій із суспільством.

Культура стратегічних комунікацій являє собою сукупність матеріальних i духовних цінностей, створених у процесі реалізації комунікативних можливостей держави. Покладена в основу таргетингу, вона дає змогу досягнути кращого порозуміння 3 цільовими аудиторіями, постійно розширювати ïx для підвищення ефективності комунікацій, a грамотне використання таргетингу дає змогу 
раціонально використовувати ресурси, отримуючи максимальний ефект.

Військові лідери є важливими суб'єктами стратегічних комунікацій, особливо в умовах відсічі збройної агресії Російської Федерації проти України. Стратегічні комунікації - це важливий інструмент, який забезпечує ефективне виконання конституційних завдань, які покладаються на ЗС України військовими лідерами, завдяки формуванню у них культури стратегічних комунікації.

Аналіз показав, що саме культура стратегічних комунікацій сучасних військових лідерів становить основу розвитку комунікаційних спроможностей MO i ЗС України, а окремі пропозиції щодо іiі формування знайшли відображення у цій статті.

Надалі матеріал статті може бути використано для розроблення теоретикометодологічних основ формування культури стратегічних комунікацій і їх складових в МО та ЗС України.

\section{СПИСОК ВИКОРИСТАНОЇ ЛІТЕРАТУРИ}

1. Про затвердження Річної національної програми під егідою Комісії Україна - НАТО на 2017 рік : Указ Президента України від 08.04.2017 р. № 103/2017. URL: https://www.president.gov.ua/documents/103201721670 (дата звернення: 12.10.2020).

2. Про затвердження Річної національної програми під егідою Комісії Україна - НАТО на 2018 рік : Указ Президента України від 28.03.2018 р. № 89/2018. URL: http://www.president.gov.ua/documents/892018-23882 (дата звернення: 12.10.2020).
3. Сальнікова О. Ф., Міщенко В. Б., Шидлюх В. В., Антоненко С. І. Використання технологій стратегічних комунікацій в системі управління Збройними Силами України. Сучасні інформачійні технології у сфері безпеки та оборони. Київ, 2017. № 3 (30). С. 61-66.

4. Вербицька А. М. Савченко В. А. Система стратегічних комунікацій Міністерства оборони України та Збройних Сил України. Наука і оборона. 2017. № 1. C. 34-39.

5. ВКП 10-00(49).01. Доктрина зі стратегічних комунікацій. Київ. 2020.

6. ВКП 7-00(03).01. Доктрина розвитку військового лідерства у Збройних Силах України. Київ, 2020.

7. Семененко В. М., Іващенко А. М., Шидлюх В. В. Організація внутрішніх комунікацій у штабах i підрозділах Збройних Сил України під час виконання завдань у районі операції Об'єднаних сил. Збірник наукових праць Центру воєнно-стратегічних досліджень Начіонального університету оборони України імені Івана Черняховського. Київ, 2020. № 1 (68). C. 6-12.

8. PO (2009) 0141, NATO Strategic Communications Policy. NATO. 2009.

9. MC 0628, NATO Military Policy on Strategic Communication. NATO. 2017.

10. NU 0692, NATO StratCom Handbook. NATO. 2017.

11. MC 0457, NATO Military Policy on Public Affairs, NATO. 2011.

12. AJP-3.10, Allied Joint Doctrine for Information Operations. NATO. 2015.

13. MC 0402, NATO Military Policy on Psychological Operations. NATO. 2012.

14. MC 0411, NATO Military Policy on Civil-Military Cooperation (CIMIC) and Civil-Military Interaction (CMI). NATO. 2014.

15. AJP-3.9, Allied Joint Doctrine for Joint Targeting. NATO. 2016.

Стаття надійшла до редакційної колегії 15.12.2020

\section{The culture of Strategic Communication as the basis for targeting}

\section{Annotation}

Strategic communications in the Armed Forces of Ukraine is a combination of communication capabilities and military activities in order to form an information environment to understand of support by Ukrainian society and the international community of the Armed Forces of Ukraine that creates a auspicious conditions for performing assigned task. However, scientific approaches to strategic communications as a culture, as well as to the rationale for the role of strategic communications culture in NATO-adopted targeting processes, remain insufficiently open and scientifically sound.

Targeting process is a joint, systematic and targeted lethal and non-lethal actions of strategic, operational and tactical levels of action, carried out in order to create specific effects, achieve military goals and desired results, with the purpose to protect Ukraine's sovereignty and territorial integrity, ensure its economic and information security.

The culture of strategic communications is a set of material and spiritual values created in the process of realization of communicative opportunities by the State on the basis of historically acquired experience and the level of its development in order to improve and harmonize measures to promote future goals.

Performed analysis showed that the culture of strategic communications of modern military leaders is the basis for the development of communication capabilities of the Ministry of Defense and the Armed Forces of Ukraine, and some proposals for its formation are reflected in this paper.

The material of the article can be used for developing theoretical and methodological foundations for the formation of a culture of strategic communications and their components in the Ministry of Defense and the Armed Forces of Ukraine.

Keywords: strategic communications; culture; targeting. 